$$
\begin{aligned}
& \text { Revista do Programa de Pós-Graduação em Ciência da Religião } \\
& \approx \text { Tema Live }-6
\end{aligned}
$$

\title{
O DIÁLOGO INTER-RELIGIOSO COMO ESTRATÉGIA DE COMBATE A INTOLERÂNCIA RELIGIOSA SOFRIDA PELAS TRADIÇÕES AFRO-BRASILEIRAS
}

\section{interreligious dialogue as a strategy to combat religious intolerance suffered by afro- brazilian traditions}

Zuleica do Carmo Garcia de Barcelos ${ }^{1}$

\begin{abstract}
Resumo: O diálogo inter-religioso está presente na contemporaneidade e é tema recorrente de reflexões por parte de autores das Ciências da Religião. Instaura a comunicação e o relacionamento entre fiéis de tradições religiosas diferentes, envolvendo partilha de vida, experiência e conhecimento. O respeito à identidade do outro e à sua religiosidade é o elemento mais importante durante o processo. Entretanto, o que se pode observar por parte de alguns grupos religiosos no Brasil, é a resistência para a escuta e a afirmação de posições de hostilidade contra denominações que não comungam de seus conceitos e crenças. No Brasil, as religiões de matriz africana são as que mais sofrem intolerância religiosa advindas de grupos pentecostais e neopentecostais. Baseada não só no desconhecimento dessas tradições, mas também no julgamento que se percebe com o diferente, a intolerância gera ações discriminatórias não somente contra as organizações religiosas, nesse caso, as de matriz afro, como a seus fiéis. A partir do reconhecimento dessa intolerância ainda sofrida pelas religiões afro-brasileiras, o objetivo desse artigo será analisar o Diálogo Interreligioso como proposta de enfrentamento do racismo religioso. O artigo terá contribuições de Cecília Mariz, Vagner Gonçalves da Silva, Roberlei Panasiewicz entre outros.
\end{abstract}

Palavras-chave: Religiões afro-brasileiras; Diálogo Inter-religioso; Intolerância.

Abstract: Interreligious dialogue is in the contemporary world and is the target of great
reflections, being a recurrent theme in the Sciences of Religion. It establishes communication
and relationships between believers of different religious traditions, involving sharing of life,

1 Mestranda em Ciências da religião da Pontifícia Universidade Católica e Minas Gerais, https://orcid.org/00000001-6106-9974, zuleicacgbarcelos@gmail.com

$$
\text { Último Andar, São Daulo, v. 24, no 38, jul-dez/2021 p. } 199 \text { - } 217
$$




$$
\begin{gathered}
\text { Revista do Programa de Pós-Graduação em Ciência da Religião } \\
\qquad 2 \text { Tema Livre }-\infty
\end{gathered}
$$

experience, and knowledge. Respect for the other's identity and their religiosity is the most important element during the process. However, what can be observed on the part of some religious groups in Brazil is the resistance to listening and establishing hostile positions against denominations that do not share their concepts and beliefs. In Brazil, African-based religions are the ones that suffer the most from religious intolerance through Pentecostal and neoPentecostal groups. Based on the preconception of what is not known, intolerance generates discriminatory actions not only against the religious institution, in this case, those of Afro matrix, but also against its faithful. Based on this intolerance still suffered by Afro-Brazilian religions, the objective of this article will be to analyze the Interreligious Dialogue as a solution to the issues of confronting Afro-Brazilian religions. The article will have contributions from Cecilia Mariz, Vagner Gonçalves da Silva, Roberlei Panasiewicz, among others.

Keywords: Afro-Brazilian religions; Inter-religious dialogue; Intolerance. 


$$
\begin{gathered}
\text { Revista do Programa de Pós-Graduação em Ciência da Religião } \\
\qquad 2 T_{\text {ema Livre }}^{-\infty}
\end{gathered}
$$

\section{Introdução}

O diálogo inter-religioso (DIR) é visto atualmente como um grande desafio para as tradições religiosas, principalmente para as afro-brasileiras. As tradições de matriz afro sofrem grande resistência por uma parte considerável da população que as enxerga como religiões demoníacas que cultuam diversos deuses. Ainda sofrem perseguições e atitudes de intolerância que não vêm isoladas, estão sempre acompanhadas de etnocentrismo, racismo, questões econômicas e manutenção do status.

Os meios de comunicação social divulgam, constantemente, vários ataques e violências sofridos pelos adeptos e pelas casas de tradições afro-brasileiras. Seus fiéis precisam aprender a lidar com a intolerância religiosa, bem como, o preconceito e os pré-conceitos de uma sociedade que julga, ataca, apedreja, queima e destrói em "nome de Jesus". Entretanto, esse povo marginalizado persiste na luta por sua sobrevivência, e a de sua tradição, mesmo apresentando marcas profundas de um fundamentalismo que condena sem conhecer. Infelizmente, esse horizonte ainda se encontra distante da realidade do cenário atual, já que demonstra embates e conflitos dolorosos revelando a violência em meio ao sagrado.

O diálogo inter-religioso² (DIR) propõe que as tradições religiosas possam conhecer-se mais, ampliar a sua percepção do sagrado ${ }^{3}$ e compreender que o mistério divino é algo inesgotável e presente de formas diferentes em diferentes religiões. Além de oportunizar a humanidade à progressão na construção da paz, no respeito pelo outro e pela vida.

2 O diálogo inter-religioso (DIR) é definido pelo Secretariado para os Não Cristãos, no documento Diálogo e Missão, como um "conjunto das relações inter-religiosas, positivas e construtivas, com pessoas e comunidades de outras confissões religiosas, para um mútuo conhecimento e um recíproco enriquecimento" (DM 3, 1984). João XXIII anunciou o Concílio Vaticano II em 25 de janeiro de 1959, após o encerramento da Semana de Oração pela Unidade dos Cristãos. Já a convocação oficial ocorreu com a publicação da "Constituição Apostólica Humanae Salutis", no dia 25 de dezembro de 1961. Em 11 de outubro de 1962, na Baślica de São Pedro, em Roma aconteceu a abertura do Concílio.

3 O conceito de sagrado tem originalmente um significado não-racional: o numinoso (do latim numen, divindade). Segundo Bruno Odélio Birck, o numen é o objeto próprio da ideia do sagrado, e, como tal, não pode ser apreendido didaticamente, mas só descrito por analogia ou metáfora; é objeto racionalmente incompreensível, apreendido unicamente pelo sentimento numinoso, que é um estado afetivo da alma (1993, p. 31).

$$
\text { Último Andar, São Daulo, v. 24, n 38, jul-dez/ } 2021 \text { p. } 199 \text { - } 217
$$


O DIR constitui uma dimensão integral da vida humana. O ser humano pode ser visto como um nó de relações, entretanto, não pode ser compreendido separadamente do outro com quem se comunica. Martin Buber (1977, p. 32) relata que, "o homem se torna EU na relação com o TU", pois é nessa relação que o sujeito constrói e aperfeiçoa sua identidade. O diálogo inter-religioso conta a reciprocidade existencial, o "intercâmbio de dons", a dinâmica relacional com o reconhecimento das semelhanças e diferenças, com isso, permite o processo de abertura, escuta e enriquecimento mútuos.

Ou seja, a comunicação e o relacionamento entre fiéis de tradições religiosas diferentes que envolve experiência, partilha de vida e conhecimento, em que preconceitos não são bem-vindos, pode ser traduzido como uma nova forma de aprendizado, por possibilitar a relação com a diferença, a apropriação de outras possibilidades e a abertura à mútua transformação.

\section{0 diálogo inter-religioso}

Foram realizados ao todo, vinte e um concílios ecumênicos durante toda a história da lgreja. O Concílio Vaticano II, teria a intenção de guardar o depósito sagrado da doutrina cristã e ensiná-lo de forma mais eficaz ao mundo moderno.

Sanchez $(2015$, p.19) relata que "a lgreja sonhada por João XXIII é aquela que adota o diálogo como método para 'voltar-se' para o mundo com a finalidade de contribuir humildemente na solução dos problemas e servir a toda humanidade". João XXIII foi considerado uma figura importante na história da Igreja católica, tendo realizado um diagnóstico da crise vivida pela instituição eclesiástica no final dos anos cinquenta do século XX.

O Concílio Vaticano II passa a representar a lgreja católica quando essa se propõe a dialogar com o mundo moderno, com a convivência com o diferente, com as diferentes visões de mundo, diferentes Igrejas cristãs e com as diferentes religiões. Foi um grande evento para a lgreja católica, inaugurou o diálogo para o mundo moderno apresentando um mundo cheio de desafios e muitos enfrentamentos para que o diálogo inter-religioso realmente acontecesse.

A trajetória da lgreja católica no caminho do diálogo inter-religioso teve seus marcos

$$
\text { Último Andar, São Daulo, v. 24, n }{ }^{\circ} \text { 38, jul-dez/ } 2021 \text { p. } 199 \text { - } 217
$$




$$
\begin{aligned}
& \text { Revista do Programa de Pós-Graduação em Ciência da Religião } \\
& \qquad 2 \text { Tema Livre }-\infty
\end{aligned}
$$

de acontecimentos e documentos elaborados tanto pelo pontificado como por organismos, no período pós-Vaticano II. Podemos classificar dois acontecimentos importantes: o primeiro ocorrido em 1964 - a criação do Secretariado para os Não Cristãos e o segundo em 1986 jornada de Oração pela Paz (o encontro de Assis). Já os documentos elaborados são sete a serem citados: 1) Encíclica Ecclesiam Suam (1964); 2) Encíclica Redemptor Homimis (1979); 3) Reflexões e orientações sobre diálogo e missão-DM (1984); 4) Encíclica Redemptoris Missio (1990); 5) Documento Diálogo e Anúncio (1991); 6) Declaração Dominus lesus (2000) e; 7) Exortação Evangelii Gaudium (2013).

Sanchez (2015, p. 89-90) defende que o diálogo inter-religioso presente nos textos conciliares abriu portas para um reconhecimento de uma nova Igreja católica disposta a compreender positivamente as demais religiões e a travar um diálogo saudável com elas. O diálogo inter-religioso segue acontecendo na vida das pessoas, dos grupos e dos organismos que buscam abraçar as iniciativas de justiça e paz.

Segundo Faustino Teixeira e Zwinglio M. Dias (2008, p. 126), "o diálogo inter-religioso instaura uma comunicação e um relacionamento entre fiéis de tradições religiosas diferentes, envolvendo partilha de vida, experiência e conhecimento". Para os autores, essa comunicação prevê um clima de abertura, empatia, acolhimento eliminando preconceitos, além de proporcionar compreensão, enriquecimento e partilha religiosa. A conversação quando disponibilizada por meio do diálogo, leva seus interlocutores à inquietude ao serem provocados e desafiados a compreender a alteridade.

○ diálogo inter-religioso permite um novo aprendizado, além do exercício da reciprocidade, já que todos os interlocutores merecem o respeito e os direitos iguais devido às suas convicções, ou seja, "(...) o reconhecimento de autenticidade e verdade" (TEIXEIRA; DIAS, 2008, p. 127).

Outro aspecto importante ao diálogo é a exigência de que os interlocutores se reconheçam como iguais e diferentes. A igualdade é vista na dignidade e no respeito que os aproxima e os identifica, enquanto a diferença é reconhecida na história de vida que faz parte de cada sujeito que dialoga. Não pode haver nenhuma forma de dominação entre eles, pois, essa invalidaria a possibilidade de diálogo. Isso não é tarefa fácil, exige estado espiritual de desapego do sentimento de superioridade, exigindo hospitalidade. O diálogo

$$
\text { Último Andar, São Daulo, v. 24, no 38, jul-dez/ } 2021 \text { p. } 199 \text { - } 217
$$




$$
\begin{aligned}
& \text { Revista do Programa de Pós-Graduação em Ciência da Religião } \\
& \qquad 2 \text { Tema Livre }
\end{aligned}
$$

só começa a ocorrer quando as tradições religiosas estão abertas em favor de um encontro acolhedor, enriquecedor que possibilite aprender com o outro nas suas diferenças.

De acordo com Roberlei Panasiewicz (2003, p.41), o documento Diálogo e Missão (28-35) sinaliza quatro formas do diálogo inter-religioso que, também, podem ser encontradas no documento Diálogo e Anúncio (42). Tais documentos foram emitidos pelo Pontifício Conselho para o Diálogo Religioso (antigo Secretariado para os não cristãos). O primeiro documento seria o Diálogo e Missão (1984), e o segundo, Diálogo e Anúncio (1991).

Os quatro níveis de encontro relacionados ao Diálogo que o catolicismo e mais amplamente, o cristianismo tem buscado concretizar são classificados pelo autor como: a) nível existencial: presença e testemunho; b) nível místico: oração e contemplação; c) nível ético: libertação e promoção do ser humano; d) nível teológico: enriquecimento e aplicação dos patrimônios religiosos.

Os níveis citados podem ser vividos separados ou de forma conjunta de acordo com o objetivo das tradições que se propõem ao diálogo.

\section{Os níveis do diálogo inter-religioso}

\subsection{Nível existencial}

O nível existencial, também entendido como presença e testemunho diz respeito "à vivência espontânea e natural dos valores internalizados pelos fiéis no interior de uma tradição cultural e religiosa" (PANASIEWICZ, 2003, p. 41). Nesse nível do diálogo são as pessoas que realmente dialogam e não as religiões. Esse diálogo implica acolhimento para com o outro, abertura e encontro interpessoal. Pode-se dizer que é por meio do percurso da vida cotidiana que o nível existencial do diálogo inter-religioso se efetiva. "Esse nível diz respeito, portanto, à vivência espontânea e natural dos valores internalizados pelos fiéis no interior de uma tradição cultural e religiosa" (PANASIEWICZ 2003, p. 42).

A abertura às partilhas no dia a dia, independentemente das diversas formas de aproximação, permite que as pessoas se relacionem umas com as outras, possibilitando depoimentos, críticas e solidariedade. A partir desses encontros sociais, as pessoas dividem suas alegrias, seus pesares e permitem que as divergências religiosas cedam à sensibilidade

$$
\text { Último Andar, São Daulo, v. 24, n 38, jul-dez/ } 2021 \text { p. } 199 \text { - } 217
$$




$$
\begin{gathered}
\text { Revista do Programa de Pós-Graduação em Ciência da Religião } \\
\qquad \text { Tema Livre }^{-\infty}
\end{gathered}
$$

e à escuta. O comportamento de uma pessoa de determinada religião pode levar outras a se interessarem em compreender como essa experiência com o sagrado possibilita tanta felicidade e satisfação. De acordo com Sanchez (2015), esse tipo de diálogo oferece diversos "arranjos" religiosos, sendo eles:

Elementos religiosos de uma religião que são apropriados pelos membros de outra religião, ganhando significação e caracterizando uma interpenetração de crenças. As fronteiras existentes entre os diferentes espaços religiosos tornam-se tênues quando se observa o comportamento dos praticantes (SANCHEZ, 2015, p. 97).

Independentemente do tipo de convivência estabelecida pelas pessoas das mais diversas religiões, diga-se que essa aproximação se torna favorável à elaboração de sínteses existenciais que são úteis para suas vidas. Por isso, o testemunho é algo importante entre pessoas de religiões diferentes. O nível existencial permite o encontro interpessoal. A vivência espontânea e a internalização dos valores de uma tradição provocam satisfação a ponto de o bem ${ }^{4}$ despertar interesse em outras pessoas de tradições diferentes.

Aqui, o diálogo inter-religioso se efetiva no percurso da vida. As pessoas de crenças diferentes se encontram nas ruas, escolas, no trabalho e dialogam partilhando suas dores e alegrias descobrindo-se solidárias ao outro independente das suas religiões, mas reagindo à sua própria maneira partindo de seus valores e crenças religiosas.

\subsection{Nível místico}

Outro nível de diálogo é o da experiência religiosa: da oração e da contemplação. O diálogo místico pode ser considerado o diálogo da partilha das conquistas espirituais. É nesse nível que homens e mulheres compartilham sua experiência contemplativa da fé perante o Sagrado. Os interlocutores participam de uma comunhão que acontece acima das palavras (conceitos ou ideias), oferecendo uma autêntica experiência espiritual.

"Nesse nível de diálogo podem ser registradas várias iniciativas exemplares

4 Os seres humanos são dotados de senso moral capaz de construir valores morais com base na experiência de outros indivíduos.

$$
\text { Último Andar, São Daulo, v. 24, n 38, jul-dez/ } 2021 \text { p. } 199 \text { - } 217
$$




$$
\begin{gathered}
\text { Revista do Programa de Pós-Graduação em Ciência da Religião } \\
\qquad 2 \text { Tema Livre }- \text { os }
\end{gathered}
$$

envolvendo o relacionamento de fiéis que buscam vivenciar a experiência de aproximação espiritual a outras tradições religiosas" (TEIXEIRA, ZWINGLIO, 2008, p. 153).

Considera-se místico aquele que vivencia uma relação como absoluto, conseguindo contemplar o mundo pelos "olhos de Deus". Isso significa, contemplar o mundo por meio do amor ${ }^{5}$ e da verdade". Para Panasiewicz (2003, p.43), "o místico é aquele que, após ter feito a experiência, única para ele, mas inesgotável no sentido e na experiência, pois, transcende o horizonte humano de compreensão, volta-se para a Humanidade e auxilia os que estão em busca de tal caminho".

A mística é um caminho aberto a todos aqueles que quiserem e tenham o interesse em trilhá-lo. É o diálogo da partilha das conquistas espirituais dos interlocutores. No nível místico, as pessoas são chamadas a participar dos rituais de outras religiões favorecendo uma autêntica experiência espiritual.

\subsection{Nível ético}

Esse é o nível do diálogo considerado por Panasiewicz (2003, p.47) como libertação e promoção do ser humano, já que é "das ações e da colaboração com objetivos de caráter humanitário, social, econômico e político que se orientem para a libertação e promoção do homem" (DM 31). É uma importante forma de diálogo, pois envolve ações e colaboração religiosa em favor da paz, de um mundo mais justo e humano. Desta forma, no nível ético há necessidade do encontro das religiões para que haja uma nova "comunhão criatural" (TEIXEIRA; DIAS, 2015, p. 152).

Na religião, a paz é vista como um acabamento perfeito de todos os seres, segundo os desígnios de Deus. Santo Agostinho7 definiu paz como a tranquilidade da ordem. Essa

\footnotetext{
5 A verdade é, pois, a qualidade do que é estável, comprovado, aquilo sobre o que se pode apoiar.

6 No campo espiritual, Deus é entendido como sendo a plenitude do amor. Pode-se dizer que Deus permitiu que o homem desenvolvesse a capacidade de demonstrar amor por meio da vida, capacitando-o a amar, sentir-se amado e viver os efeitos deste amor. (grifo meu)
}

7 Agostinho é um dos poucos pensadores que oferece uma reflexão profunda sobre a paz e define a ordem como uma disposição de coisas iguais e desiguais num padrão em que cada coisa ocupa sua posição apropriada (Agostinho, XIX, 13). Para Santo Agostinho, onde há paz, há ordem.

$$
\text { Último Andar, São Daulo, v. 24, n 38, jul-dez/2021 p. } 199 \text { - } 217
$$


ordem seria indicada pela disposição dos seres de acordo com "sua natureza e seu fim"8.

Dessa forma, o nível ético, é o diálogo da abertura ao outro para o encontro da paz, visando a união das tradições religiosas para caminharem em harmonia. Segundo Panasiewicz (2003, p.49), "é na articulação dialógica entre nações e tradições religiosas que emergirá a paz. (...) todas as pessoas, em suas religiões ou em suas culturas, são responsáveis pela construção da justiça e da paz." Ou seja, não deixa de ser uma luta particular, mas também comunitária.

É no diálogo entre nações e tradições religiosas que a paz acontecerá. Muitas propostas inovadoras poderiam nascer dos encontros inter-religiosos promovendo a defesa da vida humana, da justiça social e da paz.

"Mais do que se preocupar com ideias, as religiões têm, nesse nível, de procurar ampliar a sua compreensão da realidade à luz da automanifestação de Deus nas várias tradições religiosas, e empreender manifestações em favor da vida. Aqui está o grande desafio ético" (PANASIEWICZ, 2003, p.49). Todas as pessoas, em suas tradições religiosas, são responsáveis pela construção da paz.

\subsection{Nível teológico}

Outra forma de diálogo é a que parte da teologia religiosa. Nesse nível, encontramse representantes das várias tradições religiosas com o objetivo de "confrontar, aprofundar e enriquecer os respectivos patrimônios religiosos, aplicar os recursos, aí contidos aos problemas que se põem à Humanidade do decurso da sua história" (DM 33).

Panasiewicz (2003, p.10), afirma que o diálogo inter-religioso se apresenta como desafio e possibilidade às tradições religiosas. Desafio porque questiona as certezas das tradições religiosas e possibilidade porque (re)avaliam seus posicionamentos. O DIR não se trata de um diálogo de conversão, mas de escuta, de respeito e a descoberta de Deus mais presente em sua história de vida. Entretanto, existem dificuldades que obstaculizam ou impedem que o DIR possa acontecer como deveria. A afirmação de superioridade de algumas tradições religiosas, a arrogância identitária e a pretensão da verdade acabam por provocar a violência, a exclusão e o conflito inter-religioso.

8 É a disposição dos seres segundo sua natureza, em seguida de acordo com seu fim, e depois de acordo com a liberdade e os meios para se moverem rumo a seu fim.

$$
\text { Último Andar, São Daulo, v. 24, n 38, jul-dez/ } 2021 \text { p. } 199 \text { - } 217
$$




\section{A intolerância religiosa, os pentecostais e neopentecostais}

No Brasil encontram-se as mais diferentes religiões, embora a grande maioria da sua população se defina cristã, ou seja, católica ou protestante. O pentecostalismo no Brasil se dividiu em três períodos ou três ondas. A primeira onda ocorre com a chegada da Congregação Cristã no período de 1910 a 1911 e o aparecimento da Assembleia de Deus. A segunda começa na década de 50 e início da década de 60, com a Igreja do Evangelho Quadrangular que surge em 1951, a Igreja Brasil para Cristo, em 1955 e em 1962, a Igreja Deus é Amor. A terceira onda é definida por Vagner Gonçalves da Silva (2007, p. 214) como o surgimento do neopentecostalismo que abrange várias igrejas do movimento de renovação cristã.

O autor afirma que em outros países, igrejas dessas vertentes do neopentecostalismo, são chamadas de carismáticas com fundamento no pentecostalismo carismático norteamericano. No Brasil, o termo carismático é destinado a um movimento da lgreja Católica. Para que houvesse a distinção das igrejas, foi na década de 1970 que começaram a utilizar o termo neopentecostalismo, utilizando doutrinas e práticas das igrejas pentecostais e do movimento carismático:

\footnotetext{
"Os fiéis neopentecostais acreditam na palavra pós-bíblica dos dons do Espírito Santo, incluindo glossolalia (falar em línguas), cura (que seria realizada a partir da prática de imposição de mãos buscando a atuação do Espírito Santo) e realização de profecias. Essas igrejas também pregam ensinamentos que são comuns em igrejas pentecostais, como a batalha espiritual (confronto espiritual diretamente contra os demônios e outras forças malignas), a realização de maldições hereditárias, possessão maligna de corpos. Esse é inclusive o foco que as igrejas neopentecostais empregam a esses ensinos e dons que as levam a ser fortemente criticadas pelos demais movimentos protestantes." (SILVA, 2007, p. 214)
}

Para Cecília Loreto Mariz (2013, p. 39), os grupos pentecostais e neopentecostais apresentam postura anti-ecumênica e de isolamento o que dificulta o DIR não somente com as religiões afro-brasileiras. A autora ainda relata que os grupos pentecostais $e$

$$
\text { Último Andar, São Daulo, v. 24, n 38, jul-dez/2021 p. } 199 \text { - } 217
$$


neopentecostais são os maiores antagonistas das religiões afro e não desacreditam no poder de seus rituais, reconhecendo-os como interlocutores competentes, mas "malignos" ou "diabólicos".

Silva (2007, p. 207) relata que o neopentecostalismo, seguindo a crença da necessidade de exterminar a presença e a ação do demônio no mundo, classifica as outras denominações religiosas como pouco engajadas ou como espaço que privilegiam ações demoníacas apontando suas divindades cultuadas, como um disfarce para o mal. Dessa forma, pode-se afirmar que as religiões facilitam ou dificultam o processo do DIR.

Embora, as religiões afro sejam os maiores alvos de preconceito no Brasil, para o diálogo inter-religioso não há demarcação de qual grupo religioso sofreu mais ou menos perseguições religiosas dentro do processo histórico de construção do Brasil, porém busca novas formas de acabar com a intolerância existente. Utilizar o debate inter-religioso como estratégia de combate a intolerância implica ações que obrigam lideranças a tomar consciência do papel exercido junto a suas comunidades. Um compromisso com a cultura de paz que leve a um tempo não só de tolerância, mas de respeito mútuo e incondicional.

Os casos de intolerância sofridos pelas religiões afro-brasileiras antes sem grande repercussão, ganham na atualidade dimensões mais visíveis por intermédio dos meios de comunicação registrados em vários pontos do Brasil. Segundo Silva (2007, p. 10), para entender melhor a extensão e a perspectiva dos casos de intolerância, foram recolhidas informações na literatura acadêmica dos últimos tempos e nas publicações da imprensa. Após serem sintetizadas e classificadas por critérios, o autor as enumerou como:

(...) 1) ataques feitos no âmbito dos cultos das igrejas neopentecostais e em seus meios de divulgação e proselitismo; 2) agressões físicas in loco contra terreiros e seus membros; 3) ataques às cerimônias religiosas afro-brasileiras realizadas em locais públicos ou aos símbolos dessas religiões existentes em tais espaços; 4) ataques a outros símbolos da herança africana no Brasil que tenham alguma relação com as religiões afro-brasileiras; 5) ataques decorrentes das alianças entre igrejas e políticos evangélicos e, finalmente; 6) as reações públicas (políticas e judiciais) dos adeptos das religiões afro-brasileiras. (SILVA, 2007, p. 10) 
Os ataques sofridos pelas religiões afro-brasileiras tornam-se evidentes nas classificações realizadas pelo autor.

Na primeira classificação, os fiéis das igrejas devem dar continuidade a obra de Jesus Cristo de combate aos demônios. Dentro das igrejas ocorre as sessões de exorcismo das entidades que são chamadas a incorporar para serem desqualificadas e expulsas para a libertação espiritual do fiel. Dos púlpitos os ataques partem para os programas religiosos como rádio, televisão, sites e até jornais impressos devido a vasta rede de comunicação dessas igrejas. Entretanto, pode-se notar que as entidades não são evocadas como Satanás, aquele encontrado na escritura bíblica, mas, são chamadas pelos nomes dos seres sagrados cultuados nas religiões de matriz africana: Exú e/ou Pomba-gira.

Já na segunda, os fiéis neopentecostais muitas vezes invadem os terreiros para destruir os altares, fazem denúncias falsas, realizam passeatas contra os terreiros entre outros tantos. Na terceira classificação dada pelo autor, as festividades religiosas ficam mais expostas em espaços públicos podendo ser acometidos de ataques verbais e destruição das oferendas e das imagens. Os atos de intolerância também chegam aos transportes coletivos.

Na quarta, símbolos da herança africana, mesmo que não sejam exatamente religiosos, mas que façam alusão a tradição afro, são estigmatizados e combatidos. Enveredando pela quinta classificação, aproveitando o poder político aliado a tais igrejas, os políticos evangélicos vêm articulando ações antagônicas ao desenvolvimento das religiões afro-brasileiras.

Sexta e última classificação, nos últimos treze anos, alguns movimentos de defesa das religiões afro-brasileiras têm aparecido no âmbito jurídico, e ações legais têm sido acionadas pelos babalorixás e ialorixás contra pastores e/ou igrejas.

Marcelo Rezende Guimarães (2004) afirma que,

A intolerância está na raiz das grandes tragédias mundiais. Foi ela que destruiu as culturas pré-colombianas e promoveu a inquisição e a caça às bruxas. Foi a intolerância religiosa que levou católicos e protestantes a se matarem mutuamente na Europa, ou hindus e muçulmanos a fazerem o mesmo na Índia. Foi a intolerância que levou países a construírem um sistema de apartheid ou a organizarem campos

$$
\text { Último Andar, São Daulo, v. 24, n 38, jul-dez/ } 2021 \text { p. } 199 \text { - } 217
$$




$$
\begin{gathered}
\text { Revista do Programa de Pós-Graduação em Ciência da Religião } \\
\qquad 2 \text { Tema Livre }- \text { os }
\end{gathered}
$$

de concentração. Por trás de cada manifestação de barbárie que a humanidade teve a infelicidade de assistir e testemunhar, o que redundou em numerosos massacres e extermínios, esconde-se a intolerância como arquétipo e estrutura fundante (GUIMARÃES, 2004, p. 28).

As agressões são em "nome de Jesus", podendo ser classificadas como um fundamentalismo religioso que ataca por uma leitura equivocada da Bíblia.

\section{As religiões afro-brasileiras e o diálogo inter-religioso}

Segundo Renato da Silveira (2006), a rejeição às religiões afro-brasileiras se instaura ainda no período escravocrata. Com o país dominado pela lgreja católica, qualquer outra religião (ou performance lida como religiosa) era entendida como uma contravenção penal. Os escravizados eram objetos nas mãos de seus senhores e não podiam exercer uma crença que não fosse a da lgreja católica. Ao chegarem no Brasil, eram proibidos de praticar suas religiões nativas.

Roger Bastide (1978, p. 35) estima que foram transportados 3.600.000 homens e mulheres da África para o Brasil entre os séculos XVI e XIX, tornando o Brasil o segundo maior importador de escravizados. Esses seres humanos vieram principalmente da Nigéria, Daomé (atual Benin), Angola, Congo e Moçambique. Apesar dos laços quebrados com a família, os escravizados ainda conseguiram manter sua herança étnica. Além das exigências por parte da Igreja católica e das instituições escravagistas, conseguiram manter a língua materna e os laços com seus países, já que sempre chegavam escravizados novos.

Entre as tradições religiosas africanas que chegaram no Brasil, vieram aqueles que cultuavam os Orixás, os Nkinsis e oVoduns. Cada divindade era representada por um aspecto da natureza e uma família em particular. Orixás e Voduns são divindades dos grupos da Nigéria e Benin, e os Nkinsis pelo território reconhecido como região Bantu. No Brasil, as divindades acabaram por tornar-se protetores dos indivíduos, já que as famílias foram separadas. Muito embora os portugueses, os espanhóis, os franceses, os holandeses e os ingleses, em seus tratados comerciais, tivessem usado a política de dividi-los em diferentes nações (para melhor governá-los) e tivessem usado critérios como a etnia e a tradição

$$
\text { Último Andar, São Daulo, v. 24, n 38, jul-dez/ } 2021 \text { p. } 199 \text { - } 217
$$


cultural, famílias foram divididas em diferentes nações. Essa divisão acontecia para evitar possíveis motins contra seus compradores, distribuídos por toda a América.

A instituição das religiões afro é um fenômeno recente na história religiosa do Brasil. O surgimento dos primeiros terreiros de Candomblé ocorreu após a libertação dos escravos. O terreiro Casa Branca do Engenho Velho, teve sua inauguração na Barroquinha em 1830 e no Engenho Velho em 1890. Outros seguiram para diferentes áreas do Brasil regionalizando assim seus ritos. Dessa forma, nasce o Candomblé na Bahia, Xangô em Pernambuco e Alagoas, Tambor de Mina no Maranhão e Pará, Batuque no Rio Grande do Sul e Macumba no Rio de Janeiro. Em cada região do país as tradições africanas sobreviveram de uma forma diferente, o que culminou na pluralidade das religiões afro-brasileiras. Cada terreiro tem sua forma particular de lidar com seus elementos, além das mais diversas combinações do sincretismo afro-brasileiro.

Como as religiões afro-brasileiras eram proibidas e os terreiros eram visitados sempre pela polícia, seus praticantes começaram a fazer uso do sincretismo católico como estratégia de sobrevivência para driblar as perseguições da lgreja e do Estado. O sincretismo entre as religiões africanas pode ser interpretado como sendo o primeiro de muitos outros ocorridos nesse processo que deu origem às religiões afro-brasileiras. Ou seja, o culto a diversos Orixás em uma mesma casa é comum entre as religiões afro-brasileiras, embora, nos países da África cada tribo cultuava apenas um Orixá, fato que exemplifica o movimento sincrético ocorrido entre as religiões afro-brasileiras.

Com o tempo, os escravos foram assimilando a religiosidade dos portugueses e empregando nos santos católicos os nomes de suas divindades. Não foi tarefa fácil, mas Xangô por exemplo, deus do trovão foi comparado a São Jerônimo, representado por um ancião, entretanto está sempre acompanhado por um leão deitado a seus pés. Obaluaê, comparado a São Lázaro sendo o primeiro o deus da varíla e o segundo é coberto de feridas. Aqui percebe-se a perspicácia dos escravizados para manter seus cultos.

Mesmo após a libertação dos escravizados em 1888, ocorre em 1889 a ratificação da Constituição Republicana e em 1890, a separação da Igreja e do Estado, a República ainda proibia o espiritismo. As religiões afro-brasileiras eram designadas como baixo espiritismo. Atualmente, é perceptível que as religiões afro-brasileiras sofrem pela resistência de

$$
\text { Último Andar, São Daulo, v. 24, no 38, jul-dez/ } 2021 \text { p. } 199 \text { - } 217
$$


uma sociedade em que líderes religiosos disputam por um lugar no mercado da fé, como pela hegemonia da representatividade. Os ataques ainda são frequentes e as religiões afro ainda são consideradas religiões de negros gerando práticas intolerantes, preconceituosas e excludentes.

Devido a essa realidade, a necessidade de aprender a lidar com os ataques de uma sociedade plural, faz com que alguns adeptos das religiões afro-brasileiras se omitam para não sofrerem com a intolerância e o preconceito de uma comunidade hostilizada a essas religiões. Já aqueles que se declaram abertamente adeptos das religiões afro, encontram a intolerância bem presente na grande maioria da população:

Não quero tolerância, eu quero respeito. Tolerar é uma forma de dizer que a minha religião está errada, mas dá para fingir que não. Preciso é que respeitem o candomblé da mesma maneira que eu respeito todas as religiões. Já vieram na porta da minha tenda espiritual e disseram que o diabo estava aqui. Bom, eu sempre respondo duramente a esse tipo de coisa e falei que realmente o diabo estava lá porque a própria pessoa tinha trazido (TRIGUEIRO, 2016, online).

Segundo Panikkar (2007, p.60), "o diálogo tem um núcleo místico não visível na superfície das relações humanas. Algo sucede no coração de cada dialogante e algo sucede no núcleo mais interno do mundo". Seria por meio do diálogo inter-religioso que a intolerância religiosa seria ao menos minimizada?

De acordo com Alexandre Kaitel e Guaraci Santos (2018, p. 14), participantes do grupo REPLUDI9, "Os líderes religiosos apontam duas questões pertinentes: a) a hegemonia católica nos processos de diálogo inter-religioso existentes e o papel coadjuvante ocupado pelas religiões tradicionais de terreiro; b) a disputa de poder ocultada por propostas de diálogo." Ou seja, para alguns líderes religiosos das religiões afro-brasileiras, o DIR é uma proposta ingênua, já que esse é de vias cristãs e que toda relação social é permeada por uma relação de poder.

Kaitel e Santos, entretanto, acreditam que vale a pena dialogar para minimizar os

9 Grupo de pesquisa em Religião, Pluralismo e Diálogo do Programa de Pós-Graduação em Ciências da Religião da Pontifícia Universidade Católica de Minas Gerais - PUC - Minas.

$$
\text { Último Andar, São Daulo, v. 24, n 38, jul-dez/ } 2021 \text { p. } 199 \text { - } 217
$$


preconceitos existentes. "Uma das ações que utilizamos para desvelar essas relações de poder é a exigência que, no diálogo com as religiões de matrizes africanas, os sujeitos do diálogo participem de celebrações dessas religiões (nível místico do diálogo)" (KAlTEL; SANTOS, 2018, p.14).

No cenário atual, a necessidade de colocar em prática o diálogo inter-religioso fica evidente, já que as religiões são marcadas muitas vezes, por conflitos políticos e econômicos. O DIR pode servir para conscientizar a respeito da diversidade religiosa e do seu valor cultural. As religiões de matriz africana, "o candomblé, a umbanda e diversas religiões afro-brasileiras, além de serem ricas em cultura e em suas funções sociais, também são pilares que constituem a nossa sociedade há muito tempo e precisam ser respeitadas" (LUIS; VELIQ, 2017, p. 3).

O diálogo inter-religioso requer "abertura de coração", estar disponível para o aprendizado com o diferente, respeitando todas as pessoas e as religiões em sua dignidade singular, além de única.

\section{Conclusão}

A incitação à intolerância religiosa, principalmente em relação às religiões de matrizes africanas, parte de discursos proferidos por líderes religiosos cristãos e até de autoridades políticas. As principais causas de perseguição e das atitudes de intolerância não vêm isoladas, estão sempre acompanhadas de etnocentrismo, racismo, questões econômicas e manutenção do status.

É histórica a luta das religiões afro-brasileiras contra a intolerância, a discriminação e o preconceito. O desrespeito, a demonização de suas divindades cultuadas, as agressões físicas e verbais, além dos atentados ao espaço físico dos terreiros são apenas algumas das atitudes de intolerância sofrida.

O diálogo inter-religioso envolve partilha de vida, de conhecimento e de experiência propiciando aos fiéis de tradições religiosas distintas, o aprendizado com o outro. Entretanto, no atual cenário os embates e conflitos contemporâneos tem dificultado a realização desse diálogo. Sentimentos agressivos e hostis carregados de ódio, de superioridade e de exclusividade da verdade são alguns pontos que dificultam o diálogo. Porém, o DIR tende a contribuir para que as pessoas encontrem sentido e que se instaurem novos padrões éticos

$$
\text { Último Andar, São Daulo, v. 24, n 38, jul-dez/ } 2021 \text { p. } 199 \text { - } 217
$$




$$
\begin{gathered}
\text { Revista do Programa de Pós-Graduação em Ciência da Religião } \\
\qquad 2 \text { Tema Livre }- \text { os }
\end{gathered}
$$

que contribuam para a boa convivência e incluam o outro, não como objeto, mas como parceiro de busca.

O DIR é, portanto, um caminho necessário para que as alteridades entrem em comunicação, além de ser fundamental para aqueles que desejam dialogar, uma vez que sem o diálogo não há realização da performance humana. O diálogo está marcado na relação eu-tu. O diálogo se instaura quando ocorre uma atitude de abertura e escuta do outro, do diferente. O desafio está em assumir o risco de sair transformado, ou seja, a abertura dada ao diálogo permite evoluir durante todo o processo.

Esse relacionamento inter-religioso deve ocorrer entre fiéis que professam sua fé específica e se mostram dispostas a aprender com o diferente. Sendo assim, esse novo aprendizado traduz a relação com a diferença e a alteridade, possibilitando a apropriação de possibilidades e a abertura à transformação mútua. Deve-se criar condições propícias para o encontro, com respeito e sensibilidade, permitindo colocar-se no lugar do outro, o que muitas vezes não é tarefa fácil.

A humildade seria uma virtude essencial para o DIR, além da abertura e respeito ao diferente. A segunda condição é apontada pela abertura ao valor da alteridade. Também é exigido a fidelidade a sua convicção religiosa e o respeito às convicções do outro. A convicção religiosa seria como um ancoradouro referencial para o DIR acontecer, já que o diálogo não visa à conversão, embora haja um risco sempre presente em toda fé religiosa. Já a experiência da humildade demanda a paciência na escuta do outro para que haja hospitalidade.

No diálogo, o objetivo não é a mudança de religião, mas a mudança de seus interlocutores e uma nova apropriação de sua fé. O diálogo inter-religioso acontece em quatro níveis ou formas que podem ser vividas separadamente ou de maneira conjunta dependendo do momento histórico específico, das tradições em diálogo e do objetivo pelo qual elas se encontram. Independente da forma a ser utilizada, a prática dialogal deve ser realizada com espírito de abertura, hospitalidade e cuidado.

$$
\text { Último Andar, São Daulo, v. 24, n 38, jul-dez/ } 2021 \text { p. } 199 \text { - } 217
$$




$$
\begin{gathered}
\text { Revista do Programa de Pós-Graduação em Ciência da Religião } \\
\qquad \text { Tema Livre }^{-\infty}
\end{gathered}
$$

\section{Referências}

BASTIDE, Roger. The African Religions of Brazil: Toward a Sociology of the Interprenetation of the Civilizations. London: John Hopkins University Press, 1978.

GUIMARÃES, Marcelo Rezende. Um novo mundo é possível. São Leopoldo: Ed. Sinodal, 2004.

KAITEL, Alexandre Frank S.; SANTOS, Guaraci M. O Diálogo Inter-religioso na perspectiva umbandista. REVISTA ÚLTIMO ANDAR: CADERNOS DE PESQUISA EM CIÊNCIA DA RELIGIÃO, SÃO PAULO, N.32, P. 2-17, DEZ 2018. DISPONIVEL EM: <HTTPS://REVISTAS.PUCSP.BR/ULTIMOANDAR/ ARTICLENIEW/38908> . ACESSO EM: 15 JUN. 2021.

LUIS, Washington; VELIQ, Fabiano. É hora de uma nova reforma: a íntima. Revista Senso. v. 2, n. 2, jun./jul. 2017. Disponível em: <https://revistasenso.com.br/religiao/e-hora-de-uma-novareforma-intima/>. Acesso em: 29 jun. 2021.

MARIZ, Cecília. Instituições tradicionais e movimentos emergentes. In: PASSOS, João Décio; USARSKI, Frank. Compêndio de Ciência da Religião. São Paulo: Paulus/Paulinas, 2013.

MARIZ,CeciliaLoreto.Perspectivas SociológicassobreoPentecostalismoeoNeopentecostalismo. Revista de Cultura Teológica, São Paulo, v.3, n.13, p.37-52, dez 1995. Disponível em: <https:// ken.pucsp.br/index.php/culturateo/article/view/14222/12122>. Acesso em: 30 maio. 2021.

MORIN, Edgar; VIVERET, Edgar. Como viver em tempo de crise? Tradução de Clóvis Marques. Rio de Janeiro: Bertrand Brasil, 2013.

PANASIEWICZ, Roberlei. Os níveis ou formas de diálogo inter-religioso: uma leitura a partir da teologia cristã. Revista Horizonte: Revista de Estudos de Teologia e Ciências da Religião, Belo Horizonte, v. 2, ed. 3, p. 39-54, $2^{\circ}$ sem 2003. Disponível em: <https://www.researchgate. net/publication/307645360_Os_niveis_ou_formas_de_dialogo_inter-religioso_uma_leitura_a_ partir_da_teologia_crista $>$. Acesso em: 18 maio. 2021.

PONTIFÍCIO CONSELHO PARA O DIÁLOGO INTER-RELIGIOSO. Diálogo e anúncio. Petrópolis: Vozes, 1991. Documentos Pontifícios n. 242.

$$
\text { Último Andar, São Daulo, v. 24, n 38, jul-dez/ } 2021 \text { p. } 199 \text { - } 217
$$




$$
\begin{gathered}
\text { Revista do Programa de Pós-Graduação em Ciência da Religião } \\
\qquad 2 \text { Tema Livre }- \text { os }
\end{gathered}
$$

SECRETARIADO para os Não-Cristãos. A lgreja e as outras religiões. São Paulo: Paulinas, 2001 (Documento Diálogo e Missão).

SILVA, Vagner Gonçalves da. Entre a gira de fé e Jesus de Nazaré: relações socioestruturais entre neopentecostalismo e religiões afro-brasileiras. In: SILVA, Vagner Gonçalves da (Org.). Intolerância religiosa. Impactos do neopentecostalismo no campo religioso afro-brasileiro. São Paulo: EDUSP, 2007, 214 p.

SILVA, Vagner Gonçalves da. Os Ataques Neopentecostais às Religiões Afro-brasileiras e aos Símbolos da Herança Africana no Brasil. In: SILVA, Vagner Gonçalves da (Org.). Intolerância religiosa. Impactos do neopentecostalismo no campo religioso afro-brasileiro. São Paulo: EDUSP, 2007, 10-24 p

SILVEIRA, Renato da. O Candomblé da Barroquinha: processo de constituição do primeiro terreiro de keto. Salvador: Maianga, $1^{a}$ ed., 2006. ISBN: 9788588543416.

TRIGUEIRO, Paulo. Dia Internacional da Tolerância levanta a discussão sobre o respeito às diferenças. Folha de Pernambuco, [S. I.], 16 nov. 2016. Disponível em: https://www. folhape.com.br/noticias/dia-internacional-da-tolerancia-levanta-a-discussao-sobre-orespeito-a/6481/. Acesso em: 10 jun. 2021.

Submetido em: 4 jul. 2021. Aprovado em: 18 out. 2021. 